\title{
Distribution of zooplankton related to environmental factors in three interconnected reservoirs: Kasseb, Mornaguia and Ghdir El Goulla (North of Tunisia)
}

\author{
Ikbel Sellami $^{1 *}$, Habib Ayadi $^{1}$, Abderrahmen Bouain $^{1}$, Lotfi Aleya ${ }^{2}$ \\ and Mohammed Alaoui Mhamdi ${ }^{3}$ \\ ${ }^{1}$ Université de Sfax, Faculté des Sciences de Sfax, Département des Sciences de la Vie, Unité de Recherche UR/05ES05 \\ Biodiversité et Écosystèmes Aquatiques, Route Soukra Km 3.5 - BP 1171 - CP 3000 Sfax, Tunisia \\ 2 Université de Franche-Comté, Laboratoire de Chrono-Environnement, UMR CNRS 6249 1, Place Leclerc, \\ 25030 Besançon cedex, France \\ ${ }^{3}$ Université Sidi-Mohammed-Ben-Abdallah, Département de Biologie, Faculté des Sciences, BP 1796, Fès-Atlas, Morocco
}

Received 30 September 2008; Accepted 9 February 2009

\begin{abstract}
The spatial and temporal distribution of zooplankton and environmental parameters in Kasseb, Mornaguia and Ghdir El Goulla reservoirs (North of Tunisia) were studied monthly from July to December 2002 in order to establish seasonal patterns, biotic and abiotic relationships for these reservoirs. In Kasseb reservoir, the zooplankton community was dominated by Acanthocyclops sp. (37.3\% of total zooplankton density) and Bosmina longirostris (32.6\% of total zooplankton density). In Mornaguia and Ghdir El Goulla, Copidodiaptomus numidicus was the most abundant species with $62.1 \%$ and $97.5 \%$ of total zooplankton density respectively. Our study indicated that the zooplankton community of Ghdir El Goulla reservoir was influenced by the impact of internal environmental factors and artificially introduced water from the two Kasseb and Mornaguia reservoirs. Highest density of zooplankton species was recorded in Kasseb reservoir, which indicated an increased tendency for eutrophication. Mornaguia and Ghdir El Goulla are oligo-mesotrophic reservoirs. Understanding the relationship between the zooplankton community and temporal distribution is important for the understanding of trophic interactions within these reservoirs.
\end{abstract}

Key words: Artificial water input / environmental factors / trophic level / Tunisia / zooplankton

\section{Introduction}

In developing Tunisia, tens of reservoirs have been constructed to satisfy people's requirements for drinking, electricity and agricultural activities. Kasseb reservoir, constructed in 1969, has many uses such as hydroelectric production, irrigation and drinking water to $30 \%$ of the population of Tunis city (600 thousand people) (DGEDA, 2004). Mornaguia and Ghdir El Goulla reservoirs are located at $126 \mathrm{~km}$ downstream from Kasseb reservoir. The water from the two reservoirs is treated then distributed to Tunis inhabitants (1.7 million people). A pipeline connects the Ghdir El Goulla reservoir to receive water from that of Kasseb and Mornaguia. However, the quality and the biodiversity of these

\footnotetext{
* Corresponding author: sellamifss@yahoo.fr
}

ecosystems are poorly known, especially with regard to plankton. Seasonal variations in zooplankton community of these reservoirs have been attributed to the internal environmental factors, abiotic (Dejen et al., 2004) and biotic interactions (Fernández-Rosado and Lucena, 2001). Zooplankton community of Ghdir El Goulla reservoir was also influenced by the artificially introduced water from both Kasseb and Mornaguia reservoirs. The species composition is important in determining the trophic level of the reservoirs (Baykal et al., 2006). Therefore, individual species may reflect the level of eutrophication (Rogozin, 2000).

This study aimed at coupling the temporal distribution of zooplankton with environmental factors in three interconnected reservoirs and at determining their trophic status on the basis of the composition and abundance of zooplankton. 

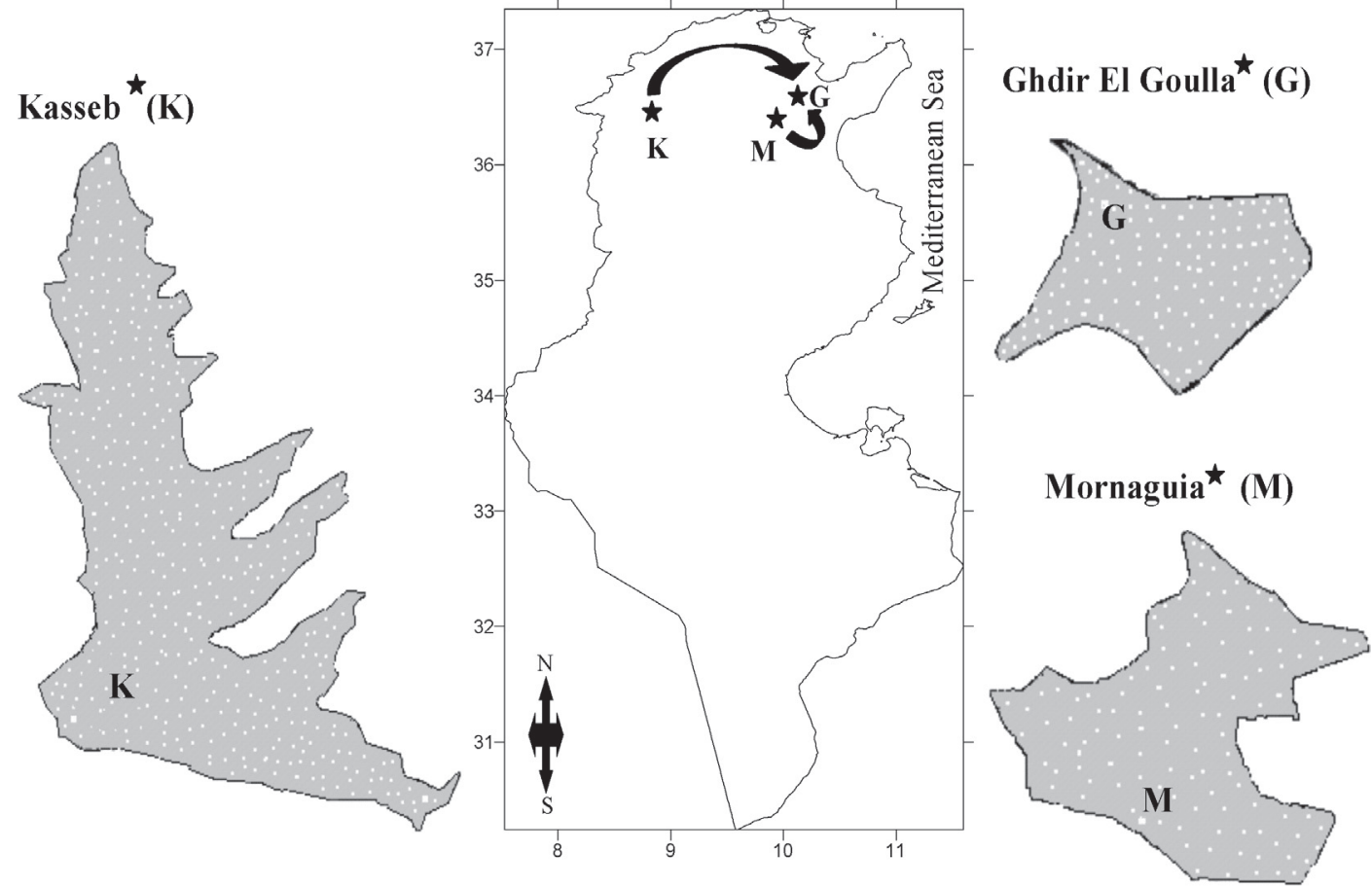

Fig. 1. Location and characteristics of the study area: Kasseb (K), Mornaguia (M) and Ghdir El Goulla (GEG) reservoirs.

\section{Materials and methods}

\section{Study site}

This study was performed in three interconnected shallow reservoirs: Kasseb (K), Mornaguia (M) and Ghdir El Goulla (G) (North of Tunisia), situated in a semi arid zone (Fig. 1). The Kasseb reservoir is at $18 \mathrm{~km}$ away from the North West of Beja city; Mornaguia and Ghdir El Goulla reservoirs are located $15 \mathrm{~km}$ away from the South-West of Tunisia. The morphometric and hydrologic characteristics of these three reservoirs are shown in Table 1.

\section{Environmental factors}

Samples were carried out from July to December 2002, in Kasseb reservoir at different levels from the surface to the deepest level $(-5 \mathrm{~m},-10 \mathrm{~m}$ and $-20 \mathrm{~m}$ : near the bottom). As for Mornaguia and Ghdir El Goulla reservoirs the samples were taken from the surface.

Monthly samples for physical and chemical analysis were taken with a 1 liter Van Dorn bottle. Water temperature was measured with a mercury glass thermometer graduated in $0.1^{\circ} \mathrm{C}$ and $\mathrm{pH}$ with $\mathrm{pH}$ meter type Met Röhm ${ }^{\circledR}$. The dissolved oxygen concentration was measured by means of Winkler methods (Rodier, 1984). Nitrogen was assayed after oxidation to the nitrate form in an alkaline medium, using potassium persulfate. The nitrate assay was based on the formation, in a concentrated sulphuric acid medium, of a phenol disulphonic acid derivative (D'Elia et al., 1977). The phosphorus concentrations were determined after mineralising the samples using the colorimetric protocol of Murphy and Riley (1962).
Phytoplankton samples were taken using a 1 liter Van Dorn bottle, simultaneously with the samples for chemical analysis. Phytoplankton enumeration was performed with an inverted microscope using the Utermöhl's (1958) method after fixation with a Lugol solution.

Sub samples $(0.5 \mathrm{~L})$ for quantification of chlorophyll $a$, were filtered using Whatman $\mathrm{GF} / \mathrm{C}$ filters $(0.45 \mu \mathrm{m}$ pore size filter and $25 \mathrm{~mm}$-diameter) and the quantity of pigments was determined with a fluorometric using a methanol extraction method.

\section{Zooplankton}

Zooplankton samples were obtained by filtering $50 \mathrm{~L}$ through a Juday plankton net (mesh size $55 \mu \mathrm{m}$ ), preserved with $4 \%$ formalin and coloured with Bengal Pink. The zooplankton was identified and counted under a binocular microscope type Leica in Dolffus chambers. The taxonomic identification was carried out according to Amoros (1984), Margaritora (1985) and Korovchinsky (1992). The zooplankton community could thus be described using data expressed in terms of density (ind. $\mathrm{L}^{-1}$ ). The level of community structure was assessed according to the diversity index as described by Shannon and Weaver (1949); it is the most popular index (Andronikova, 1993). This index was calculated from the annual average density of zooplanktonic species:

$$
\mathrm{H}^{\prime}=-\sum_{i=1}^{\mathrm{S}} \frac{n_{i}}{N} \times \log _{2} \frac{n_{i}}{N}
$$

where $n_{i}$ is the average density of $i$ species, and $N$ is the average density of the entire community, respectively. 
Table 1. Morphometric and hydrologic characteristics of the studied reservoirs (meteorology service and agricultural Minister of Tunisia, 2002).

\begin{tabular}{llll}
\hline & \multicolumn{1}{c}{ Kasseb } & Mornaguia & Ghdir El Goulla \\
\hline Latitude & $36^{\circ} 45^{\prime} 30^{\prime \prime} \mathrm{N}$ & $36^{\circ} 44^{\prime} \mathrm{N}$ & $36^{\circ} 44^{\prime} \mathrm{N}$ \\
Longitude & $09^{\circ} 50^{\prime \prime} \mathrm{E}$ & $09^{\circ} 58^{\prime} 50^{\prime \prime} \mathrm{E}$ & $09^{\circ} 58^{\prime} 50^{\prime \prime} \mathrm{E}$ \\
Construction & 1969 & 1982 & 1968 \\
Surface area (ha) & 435 & 150 & 40 \\
Maximum depth (m) & 57 & 33 & 32 \\
Volume $\left(\mathrm{Mm}^{3}\right)$ & 82 & 15 & 3 \\
Water temperature $\left({ }^{\circ} \mathrm{C}\right)$ & 18.6 & 20 & 19.2 \\
Annual mean precipitation $(\mathrm{mm})$ & 631 & 412 & 380 \\
Annual mean evaporation $(\mathrm{mm})$ & 1678 & 1757 & 1520 \\
\hline
\end{tabular}

\section{Trophic index}

Two trophic state indexes were determined; the classical freshwater TSI of Carlson and Simpson (1996) and Burns and Bryers (2000). TSI was calculated with chlorophyll $a\left(\mathrm{mg} . \mathrm{L}^{-1}\right)$ and total phosphorus $\left(\mathrm{mg} . \mathrm{L}^{-1}\right)$ using the following equations (Carlson and Simpson, 1996; Burns and Bryers, 2000):

$$
\begin{gathered}
\operatorname{TSI}_{\mathrm{C}}(\mathrm{Chl} a)=9.81 \ln (\mathrm{Chl} a)+30.6 \\
\operatorname{TSI}_{\mathrm{C}}(\mathrm{TP})=14.42 \ln (\mathrm{TP})+4.15 \\
\mathrm{TL}_{\mathrm{B}}(\mathrm{Chl} a)=2.22+2.54 \log (\mathrm{Chl} a) \\
\mathrm{TL}_{\mathrm{B}}(\mathrm{TP})=0.218+2.92 \log (\mathrm{TP}) .
\end{gathered}
$$

\section{Statistical analysis}

The data recorded in this study were examined with a normalized principal component analysis (PCA) (Chessel and Dolédec, 1992). Physico-chemical (water temperature, dissolved oxygen, total nitrogen and total phosphorus) and biological parameters (chlorophyll $a$, phytoplankton and zooplankton) assessing over 12 observations were considered.

The discrimination between months was assessed by examining the projection of the plots of the extracted factors on a factorial plan consisting of the statistically significant axes of the PCA analysis. Simple $\log (x+1)$ transformation was applied to data in order to correctly stabilize the variance (Frontier, 1973).

The potential relationships between variables were tested by Pearson's correlation coefficient. Significance level was fixed at 0.05 for all the statistical analyses.

\section{Results}

\section{Environmental parameters}

The water temperature in the Kasseb reservoir varied from $12^{\circ} \mathrm{C}$ in December along the water column to
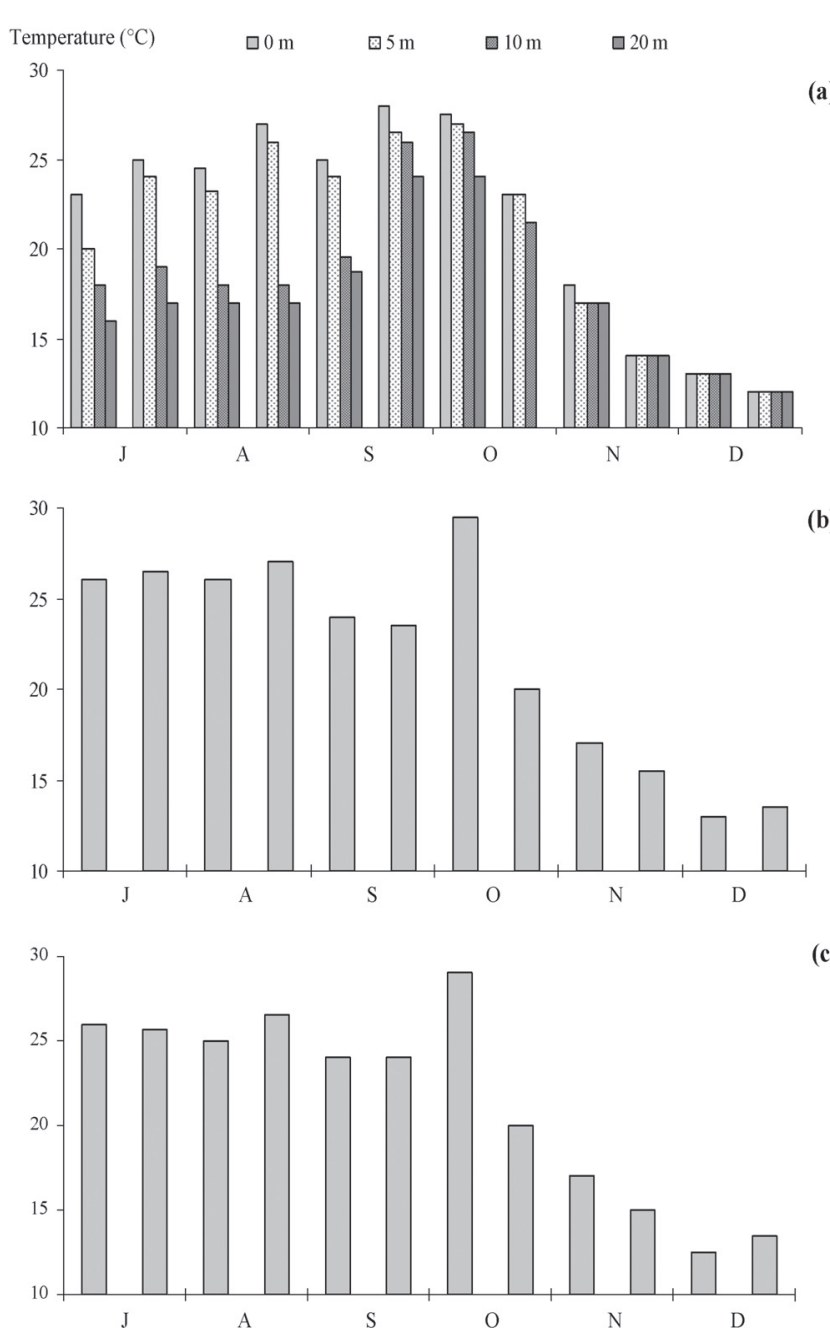

Fig. 2. Spatial and temporal variation of the water temperature in Kasseb (a), Mornaguia (b) and Ghdir El Goulla (c) reservoirs.

$28^{\circ} \mathrm{C}$ in September at surface (mean \pm s.d. $=19.6 \pm 5.1^{\circ} \mathrm{C}$ ) (Fig. 2a), with spatial and temporal fluctuations typical of those a warm monomictic reservoir. The temperature of water column increased markedly from July to September from surfaces and $5 \mathrm{~m}$ depth. The water temperature ranged from $13{ }^{\circ} \mathrm{C}$ in December to $29.5^{\circ} \mathrm{C}$ in October (mean \pm s.d. $=21.8 \pm 5.8^{\circ} \mathrm{C}$ ) and $12.5^{\circ} \mathrm{C}$ in December to $29^{\circ} \mathrm{C}$ in October (mean \pm s.d. $=21.5 \pm 5.7^{\circ} \mathrm{C}$ ) in 


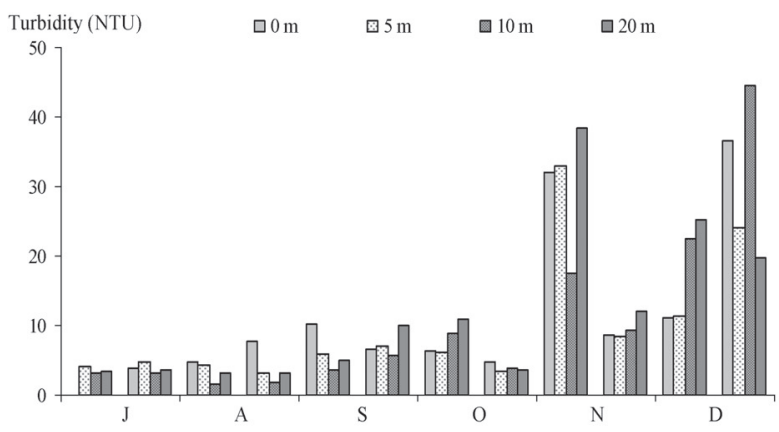

(a)

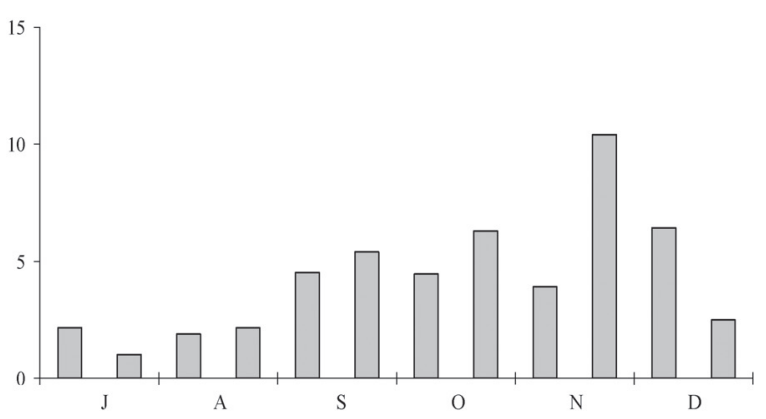

(c)

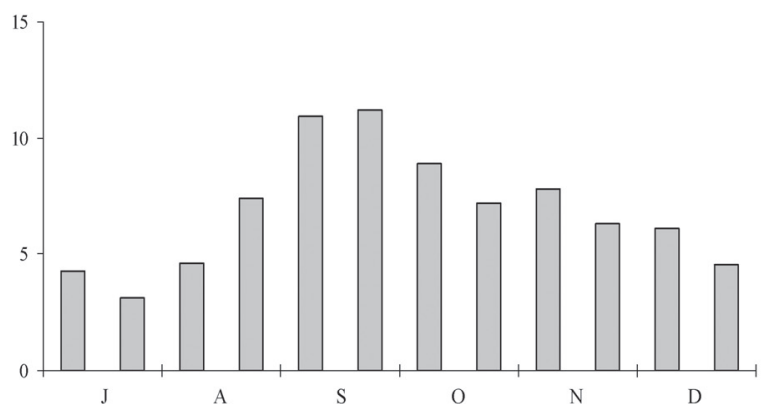

Fig. 3. Spatial and temporal variation of the turbidity in Kasseb (a), Mornaguia (b) and Ghdir El Goulla (c) reservoirs.

Mornaguia and Ghdir El Goulla reservoirs respectively (Figs. $2 \mathrm{~b}$ and $2 \mathrm{c}$ ). The mean values of dissolved oxygen concentrations measured in the surface were $8.8 \pm$ $1.5 \mathrm{mg} . \mathrm{L}^{-1}, 8.7 \pm 0.9 \mathrm{mg} . \mathrm{L}^{-1}$ and $8.6 \pm 0.7 \mathrm{mg} . \mathrm{L}^{-1}$ in Kasseb, Mornaguia and Ghdir El Goulla reservoirs respectively. Water surface $\mathrm{pH}$ ranged from 7.9 in July to 8.4 in December (mean \pm s.d. $=8.1 \pm 0.1$ ); from 7.6 in November to 8.2 in July (mean \pm s.d. $=7.9 \pm 0.2$ ); and from 7.9 in November to 8.3 in July (mean \pm s.d. = $8.1 \pm 0.1$ ) in Kasseb, Mornaguia and Ghdir El Goulla reservoirs respectively. Turbidity ranged from 1.6 NTU in August at a depth of $10 \mathrm{~m}$ to $44.6 \mathrm{NTU}$ in December at a depth of $10 \mathrm{~m}$ (mean \pm s.d. $=10.8 \pm 10.7$ NTU) (Fig. 3a); from 1.0 NTU in July to $10.4 \mathrm{NTU}$ in November (mean \pm s.d. $=6.9 \pm 2.6$ NTU) (Fig. 3b); and from 3.1 NTU in July to $11.2 \mathrm{NTU}$ in September (mean \pm s.d. $=6.9 \pm 2.6$ NTU) (Fig. 3c) in Kasseb, Mornaguia and Ghdir El Goulla reservoirs respectively. The total nitrogen concentrations varied from $0.5 \mathrm{mg} . \mathrm{L}^{-1}$ in September at a depth of $10 \mathrm{~m}$ to $10.9 \mathrm{mg} . \mathrm{L}^{-1}$ in December at a depth of $5 \mathrm{~m}$ (mean \pm s.d. $=2.5 \pm 3.4 \mathrm{mg} . \mathrm{L}^{-1}$ ) (Fig. 4a); from $0.6 \mathrm{mg} . \mathrm{L}^{-1}$ in the end of December to $6.1 \mathrm{mg} . \mathrm{L}^{-1}$ in the
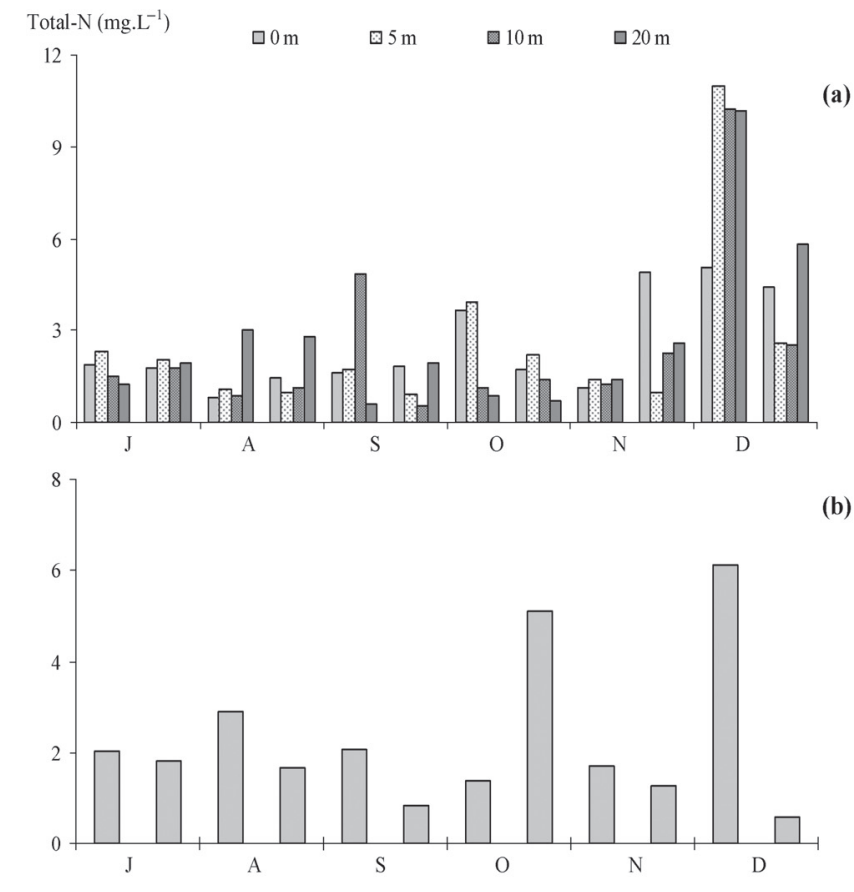

(b)

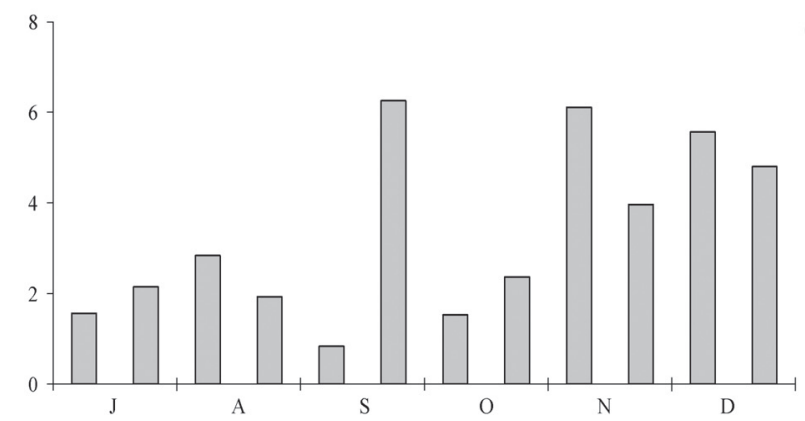

Fig. 4. Spatial and temporal variation of the total nitrogen in Kasseb (a), Mornaguia (b) and Ghdir El Goulla (c) reservoirs.

beginning of December (mean \pm s.d. $=2.2 \pm 1.7 \mathrm{mg} . \mathrm{L}^{-1}$ ) (Fig. 4b); and from $0.8 \mathrm{mg} . \mathrm{L}^{-1}$ in the beginning of September to $6.3 \mathrm{mg} . \mathrm{L}^{-1}$ in the end of September (mean \pm s.d. $=3.3 \pm 1.9 \mathrm{mg} . \mathrm{L}^{-1}$ ) (Fig. 4c) in the Kasseb, Mornaguia and Ghdir El Goulla reservoirs respectively. In these three reservoirs the highest values of total nitrogen concentrations in autumn was probably obtained by dividing inputs arriving to the reservoirs by the surface of each catchments. The total phosphorus concentrations fluctuated from $0.003 \mathrm{mg} . \mathrm{L}^{-1}$ in September at a depth of $20 \mathrm{~m}$ to $0.2 \mathrm{mg} . \mathrm{L}^{-1}$ in August at a depth of $10 \mathrm{~m}$ (mean \pm s.d. $=0.06 \pm 0.04 \mathrm{mg} . \mathrm{L}^{-1}$ ) (Fig. $5 \mathrm{a}$ ); from $0.02 \mathrm{mg} . \mathrm{L}^{-1}$ in November to $0.1 \mathrm{mg} . \mathrm{L}^{-1}$ in October (mean \pm s.d. $=0.08 \pm$ $0.06 \mathrm{mg} . \mathrm{L}^{-1}$ ) (Fig. 5b); and from $0.01 \mathrm{mg} . \mathrm{L}^{-1}$ in December to $0.1 \mathrm{mg} . \mathrm{L}^{-1}$ in August (mean \pm s.d. $=0.07 \pm$ 0.04 mg. $\mathrm{L}^{-1}$ ) (Fig. 5c) in the Kasseb, Mornaguia and Ghdir El Goulla reservoirs respectively. In these three reservoirs the highest values of total phosphorus concentrations in autumn were probably the result of released sediments.

The total phytoplankton abundance ranged from $0.1 \times$ $10^{6}$ cells. $\mathrm{L}^{-1}$ in July at a depth of $20 \mathrm{~m}$ (Fig. 6d) to 


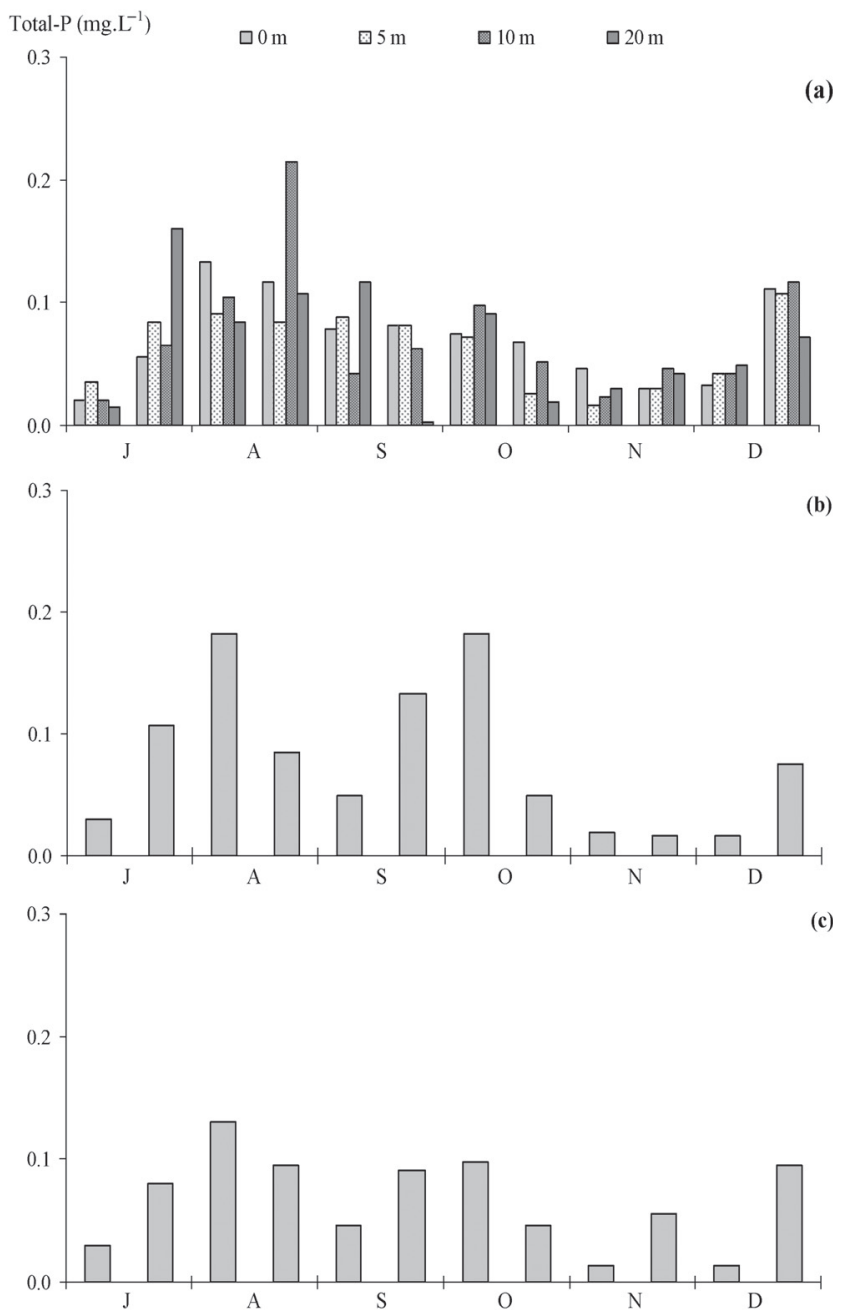

Fig. 5. Spatial and temporal variation of the total phosphorus in Kasseb (a), Mornaguia (b) and Ghdir El Goulla (c) reservoirs.

$5.7 \times 10^{6}$ cells. $\mathrm{L}^{-1}$ in August in the surface (Fig. 6a) $\left(\right.$ mean \pm s.d. $=1.3 \times 10^{6} \pm 1.3 \times 10^{6}$ cells. L $\left.^{-1}\right)$; from $0.3 \times$ $10^{6}$ cells. $\mathrm{L}^{-1}$ in December to $1.6 \times 10^{6}$ cells. $\mathrm{L}^{-1}$ in July (Fig. 7a) $\left(\right.$ mean \pm s.d. $=0.9 \times 10^{6} \pm 0.3 \times 10^{6}$ cells. $\mathrm{L}^{-1}$ ); and from $0.2 \times 10^{6}$ cells. $\mathrm{L}^{-1}$ in October to $1.8 \times$ $10^{6}$ cells. L $^{-1}$ in July (Fig. 7 b) (mean \pm s.d. $=0.8 \times 10^{6} \pm$ $0.5 \times 10^{6}$ cells. $\mathrm{L}^{-1}$ ) in Kasseb, Mornaguia and Ghdir El Goulla reservoirs respectively. Chlorophyll $a$ concentrations ranged from $0.07 \mu \mathrm{g} . \mathrm{L}^{-1}$ in November at a depth of $20 \mathrm{~m}$ (Fig. 6d) to $5.7 \mu \mathrm{g} . \mathrm{L}^{-1}$ in September at a depth of $5 \mathrm{~m}$ (Fig. 6b) (mean \pm s.d. $\left.=1.0 \pm 1.1 \mu \mathrm{g} . \mathrm{L}^{-1}\right)$; from $0.07 \mu \mathrm{g} . \mathrm{L}^{-1}$ in July to $1.3 \mu \mathrm{g} . \mathrm{L}^{-1}$ in December (Fig. 7a) (mean \pm s.d. $=0.8 \pm 0.4 \mu \mathrm{g} . \mathrm{L}^{-1}$ ); and from $0.09 \mu \mathrm{g} . \mathrm{L}^{-1}$ in October to $2.0 \mu \mathrm{g} . \mathrm{L}^{-1}$ in December (Fig. 7b) (mean \pm s.d. $\left.=0.6 \pm 0.5 \mu \mathrm{g} . \mathrm{L}^{-1}\right)$ in Kasseb, Mornaguia and Ghdir El Goulla reservoirs respectively.

\section{Distribution of zooplankton}

Considering the three reservoirs, a total of 8 species of zooplankton was recorded, consisting of 4 species

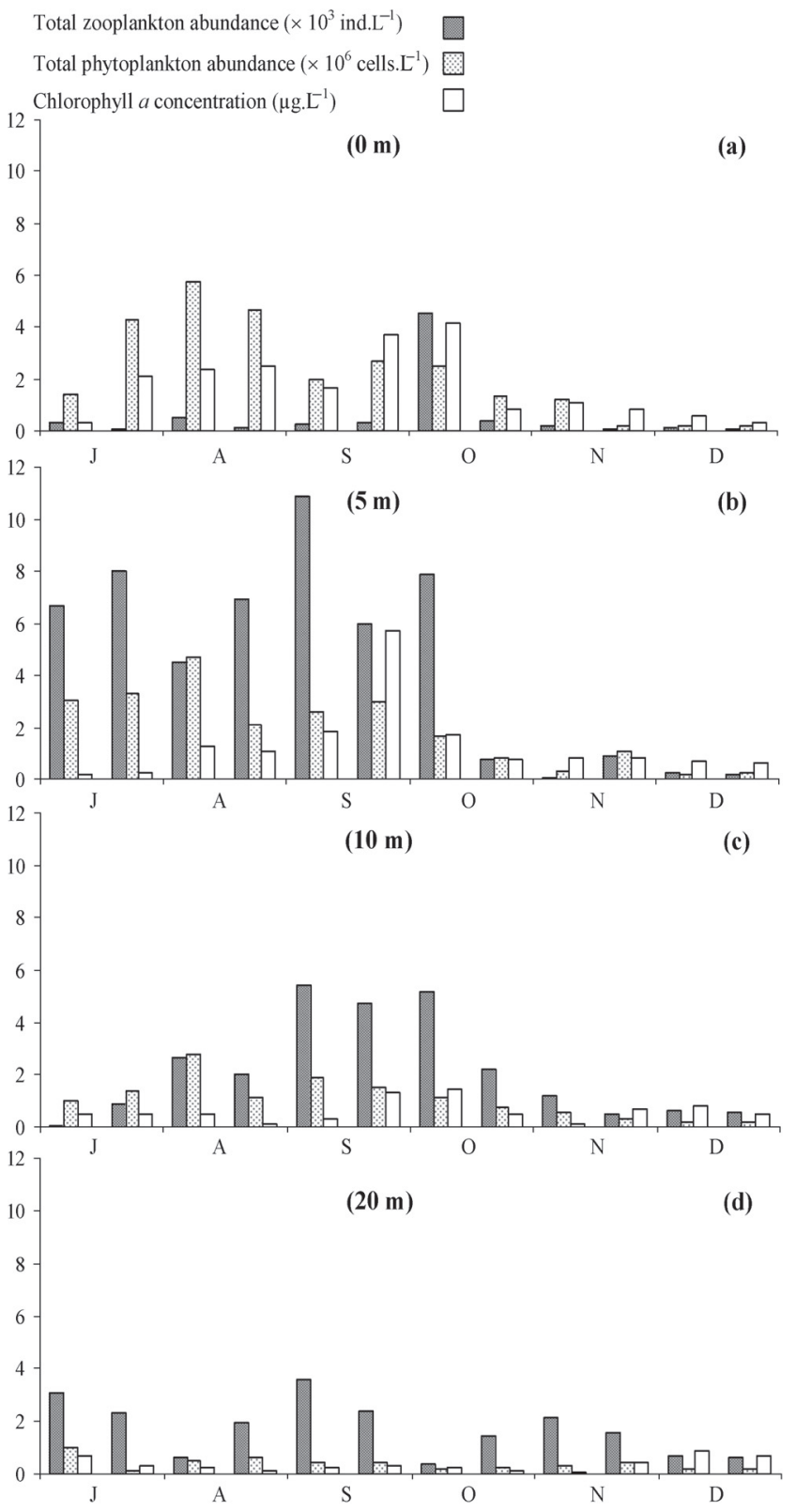

Fig. 6. Spatial and temporal distribution of total phytoplankton, chlorophyll $a$ and total zooplankton along the water column in Kasseb reservoir: $0 \mathrm{~m}$ (a), $-5 \mathrm{~m}$ (b), $-10 \mathrm{~m}$ (c) and $-20 \mathrm{~m}$ (d).

of Cladocerans (Bosmina longirostris, Diaphanosoma brachyurum, Daphnia longispina, and Ceriodaphnia quadrangula), 3 species of copepods (Copidodiaptomus numidicus, Eudiaptomus sp. and Acanthocyclops sp.), and 1 species of rotifer (Keratella quadrata). The copepods were most abundant in the three reservoirs. In Kasseb reservoir, the dominant species is Acanthocyclops sp. followed by Bosmina longirostris. In Mornaguia reservoir, the Copidodiaptomus numidicus and Acanthocyclops sp. are the most abundant species. Ghdir El Goulla is receiving the water from Kasseb and Mornaguia. Ghdir El Goulla zooplankton community is totally mixed with the species coming from these two reservoirs. Therefore the most dominant species is Copidodiaptomus numidicus 
Table 2. Zooplankton species found in Kasseb, Mornaguia and Ghdir El Goulla reservoirs, with density of dominant species (mean number of individuals per liter; ind. $\mathrm{L}^{-1} \pm \mathrm{SE}$ ).

\begin{tabular}{lccc}
\hline & & Reservoirs & Ghdir El Goulla \\
\cline { 2 - 4 } Copidodiaptomus numidicus & Kasseb & Mornaguia & $204.4 \pm 304$ \\
Adults & $8.8 \pm 53.9$ & $308.7 \pm 264.9$ & $4.0 \pm 10.5$ \\
Copepodits & $7.8 \pm 46.9$ & $162.0 \pm 222.3$ & $29.7 \pm 36.8$ \\
Nauplii & $0.6 \pm 4.6$ & $84.8 \pm 57.4$ & $170.6 \pm 315.5$ \\
\hline Eudiaptomus sp. & $0.3 \pm 2.3$ & $61.8 \pm 61.2$ & $12.1 \pm 19.0$ \\
Adults & $1.5 \pm 6.4$ & $59.5 \pm 118.3$ & $2.7 \pm 6.1$ \\
Nauplii & $0.08 \pm 0.5$ & $54.1 \pm 103.1$ & $9.4 \pm 16.5$ \\
\hline Acanthocyclops sp. & $1.4 \pm 5.8$ & $5.4 \pm 6.6$ & $18.5 \pm 16.1$ \\
Adults & $1772.3 \pm 3140.1$ & $1.3 \pm 4.5$ \\
Copepodits & $265.7 \pm 438.8$ & $301.9 \pm 635.5$ & $15.7 \pm 17.0$ \\
Nauplii & $1339.9 \pm 186.54$ & $74.4 \pm 153.1$ & $1.3 \pm 3.3$ \\
\hline Bosmina longirostris & $166.6 \pm 833.7$ & $226.1 \pm 538.0$ & $1.3 \pm 3.3$ \\
Diaphanosoma brachyurum & $270.2 \pm 889.6$ & $1.3 \pm 3.3$ & $9.4 \pm 9.4$ \\
Daphnia longispina & $232.8 \pm 468.5$ & $83.9 \pm 197.7$ & 0 \\
Ceriodaphnia quadrangula & $126.2 \pm 247.8$ & $235.6 \pm 312.5$ & 0 \\
\hline Keratella quadrata & $8.9 \pm 4.2$ & 0 & 0 \\
\hline
\end{tabular}
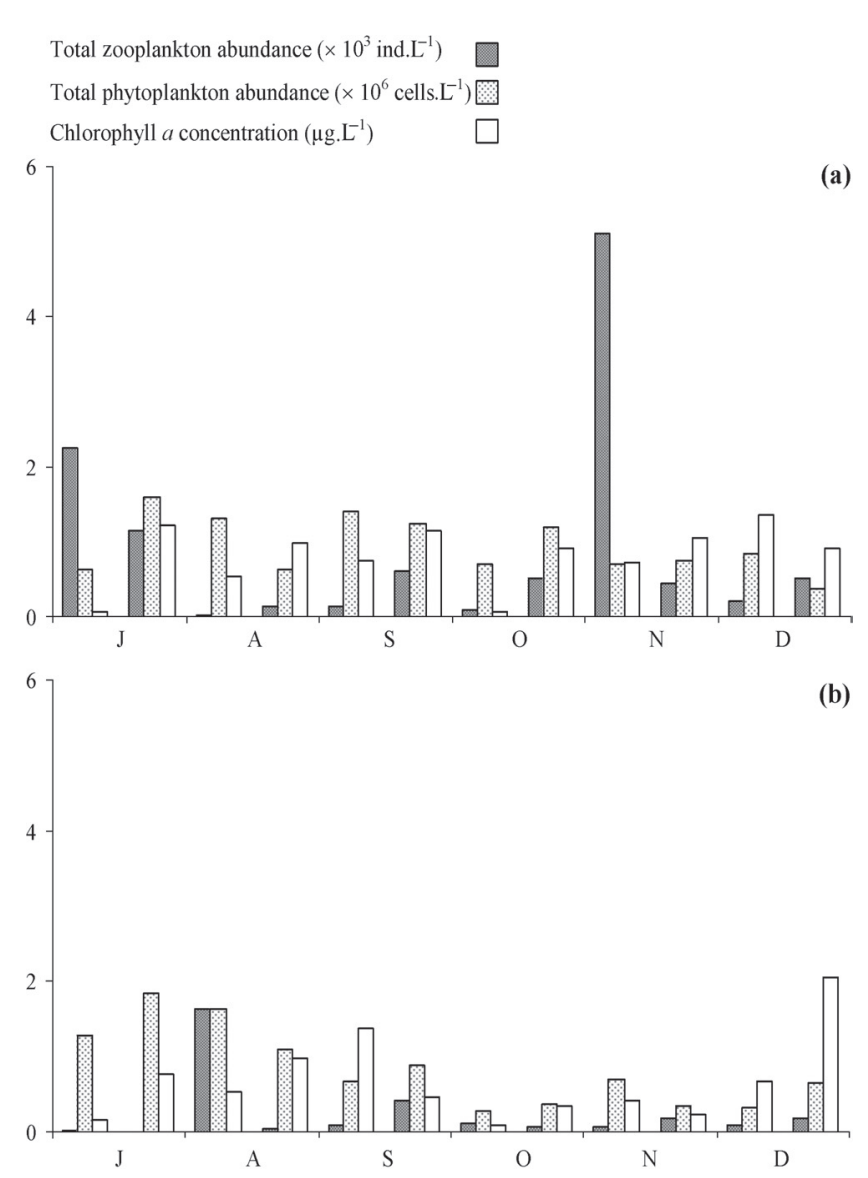

Fig. 7. Spatial and temporal distribution of total zooplankton, total phytoplankton in Mornaguia (a) and Ghdir El Goulla (b) reservoirs.

followed by Acanthocyclops sp. Daphnia longispina and Ceriodaphnia quadrangula are present only in Kasseb reservoir. Rotifers are absent in Ghdir El Goulla reservoir (Table 2).
In Kasseb reservoir, the total zooplankton abundance varied from $0.04 \times 10^{3}$ ind. $\mathrm{L}^{-1}$ in July at a depth of $10 \mathrm{~m}$ to $10.8 \times 10^{3}$ ind. $\mathrm{L}^{-1}$ in September at a depth of $10 \mathrm{~m}$ $\left(\right.$ mean \pm s.d. $=2.2 \times 10^{3} \pm 2.6 \times 10^{3}$ ind. $\left.L^{-1}\right) \quad($ Fig. $6 \mathrm{c})$. During the rainy period (November and December), the total zooplankton density was found to decrease. It was higher during the warmer periods (July, August and September). Constantly, Acanthocyclops sp. largely dominated the zooplankton community in this reservoir. The maximum density of $9.7 \times 10^{3}$ ind. $\mathrm{L}^{-1}$ was showed in September at $5 \mathrm{~m}$ layer $\left(\right.$ mean \pm s.d. $=1.6 \times 10^{3} \pm 2.1 \times$ $10^{3}$ ind. $\mathrm{L}^{-1}$ ) (Fig. 8a). The copepodits exhibited the highest level $\left(\right.$ mean \pm s.d. $=1.3 \times 10^{3} \pm 1.8 \times 10^{3}$ ind. $\left.^{-1}\right)$ (Table 2).

The total zooplankton abundance varied from 0.03 in July to $5.1 \times 10^{3}$ ind. $\mathrm{L}^{-1}$ in August (mean \pm s.d. $=0.9 \times$ $10^{3} \pm 1.4 \times 10^{3}$ ind. $\mathrm{L}^{-1}$ ) (Fig. 7a) and from 0 in July to $1.6 \times 10^{3}$ ind. $\mathrm{L}^{-1}$ in August (mean \pm s.d. $=0.2 \times 10^{3} \pm$ $0.4 \times 10^{3}$ ind. $\mathrm{L}^{-1}$ ) (Fig. 7b) in Mornaguia and Ghdir El Goulla respectively. The species Copidodiaptomus numidicus was the most dominant species in these reservoirs. The maximum density of this species averaging $1.6 \times$ $10^{3}$ in July (mean \pm s.d. $=0.3 \times 10^{3} \pm 0.4 \times 10^{3}$ ind. L $^{-1}$ ) (Fig. 8 b) and $1.6 \times 10^{3}$ ind. $\mathrm{L}^{-1}$ in August (mean \pm s.d. $=$ $0.2 \times 10^{3} \pm 0.4 \times 10^{3}$ ind. L $^{-1}$ ) (Fig. $8 \mathrm{c}$ ) in Mornaguia and Ghdir El Goulla respectively. The adults and Nauplii exhibited the highest level averaging $0.1 \times 10^{3} \pm 0.2 \times$ $10^{3}$ ind. $\mathrm{L}^{-1}$ and $0.1 \times 10^{3} \pm 0.3 \times 10^{3}$ ind. $\mathrm{L}^{-1}$ respectively in Mornaguia and Ghdir El Goulla (Table 2).

In Kasseb reservoir, a higher community diversification showed in December $\left(\mathrm{H}^{\prime}=1.8\right.$ bits ind. $\left.\mathrm{L}^{-1}\right)($ mean \pm s.d. $=0.8 \pm 0.6$ bits ind. $\left.\mathrm{L}^{-1}\right)$ is due to the simultaneous presence of 4 species (Acanthocyclops sp., Eudiaptomus sp., Bosmina longirostris and Daphnia longispina). In Mornaguia and Ghdir El Goulla, the diversification reached a maximum of 1.7 bits ind. $L^{-1}$ in September $\left(\right.$ mean \pm s.d. $=1.0 \pm 0.4$ bits ind. $\mathrm{L}^{-1}$ ) and 1.5 bits ind. $\mathrm{L}^{-1}$ in August (mean \pm s.d. $=0.9 \pm 0.5$ bits ind. $L^{-1}$ ) due to 

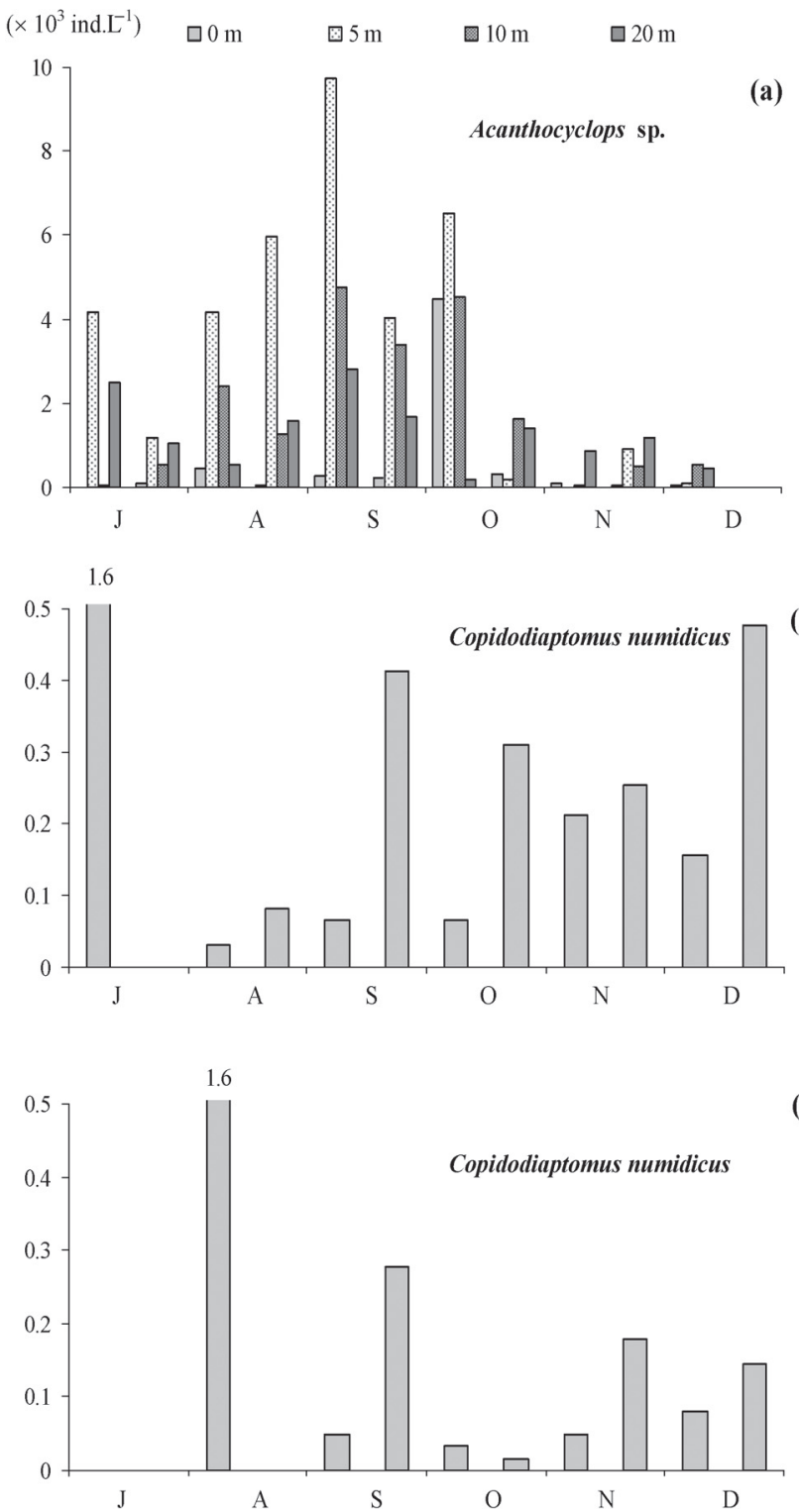

Fig. 8. Spatial and temporal distribution of Acanthocyclops sp. species along the water column in Kasseb (a) and Copidodiaptomus numidicus species in Mornaguia (b) and Ghdir El Goulla (c) reservoirs.

the presence of 4 species (Copidodiaptomus numidicus, Eudiaptomus sp., and Acanthocyclops sp. and Diaphanosoma brachyurum) and 3 species (Acanthocyclops sp., Bosmina longirostris and Diaphanosoma brachyurum) respectively.

The maximum density of the species Copidodiaptomus numidicus $\left(0.3 \times 10^{3} \pm 0.2 \times 10^{3}\right.$ ind. $\left.\mathrm{L}^{-1}\right) \quad($ Table 2), Eudiaptomus sp. $\left(0.05 \times 10^{3} \pm 0.1 \times 10^{3} \mathrm{ind}^{-\mathrm{L}^{-1}}\right)($ Table 2$)$, Diaphanosoma brachyurum $\left(0.2 \times 10^{3} \pm 0.3 \times 10^{3}\right.$ ind. $\left.^{-1}\right)$ (Table 2) and Keratella quadrata $\left(0.01 \times 10^{3} \pm 0.03 \times\right.$ $10^{3}$ ind. $\mathrm{L}^{-1}$ ) (Table 2) were showed in Mornaguia reservoir. Yet, the species Acanthocyclops sp. $\left(1.7 \times 10^{3} \pm 3.1 \times\right.$ $10^{3}$ ind. $\left.\mathrm{L}^{-1}\right)$ (Table 2) and Bosmina longirostris $(0.2 \times$ $10^{3} \pm 0.8 \times 10^{3}$ ind. $\left.^{-1}\right)($ Table 2$)$ presented a high density in Kasseb reservoir. Moreover a higher community diversification was showed in this reservoir. On the contrary, the low diversity and density of zooplankton species occurred in Ghdir El Goulla reservoir.

\section{Community analysis}

A principal Component Analysis (PCA) was performed for total zooplankton, total phytoplankton abundance and environmental variables in the Kasseb (Fig. 9a), Mornaguia (Fig. 9b) and Ghdir El Goulla reservoirs (Fig. 9c). Our interpretation will concentrate on the first two eigenvectors since they account for $49.5 \%, 60.7 \%$ and $48.7 \%$ of total variance respectively.

PCA results for mean values of environmental and biological variables (Fig. 10a) and for each sampling data (Fig. 10b) in the three reservoirs were further studied. The percentage of total variance explained by the first two axes was $54.7 \%$ (first $=40.8$, second $=13.8$ ) (Fig. 10a). In the positive region of axis 1 , the variables were associated with trophic indices (total phosphorus and chlorophyll $a$ ).

\section{Discussion}

In the three reservoirs, the zooplankton community showed variations in density in relation to physicochemical variables. The same results were obtained through many studies indicating that zooplankton abundance and population dynamics depended on the chemical and physical composition of water (Ludovisi and Poletti, 2003; Zadereev and Tolomeyev, 2007).

The highest zooplankton densities were found during the warm period (July, August and September), except a peak was showed in November in Mornaguia reservoir, which can be related to temperature. This is in accordance with the study of Karabin et al. (1997) concluding that temperature is the most important factors influencing the zooplankton communities.

In contrast, zooplankton densities decreased during the rainy period (November and December). The same results were found by Guevara et al. (2009) showing that a negative association observed between zooplankton density and rainfall intensity. Thus, in the three reservoirs, zooplankton abundance has been reported to be influenced by repeated internal environmental fluctuations of which rainfall is a primary steering factor. This is in accordance with the study of Osore et al. (1997).

Furthermore, zooplankton densities were not correlated with oxygen concentration because it was relatively high in the three reservoirs $\left(8.8 \pm 1.5 \mathrm{mg} . \mathrm{L}^{-1}\right.$ (Kasseb), $8.7 \pm 0.9 \mathrm{mg} . \mathrm{L}^{-1}$ (Mornaguia) and $8.6 \pm 0.7 \mathrm{mg} . \mathrm{L}^{-1}$ (Ghdir El Goulla)). Oxygen concentrations affected zooplankton only at much lower concentrations $\left(<2.5 \mathrm{mg} . \mathrm{L}^{-1}\right)$ (Aka et al., 2000).

Moreover, the strong decrease in zooplankton densities in November and December coincided with a consecutive decrease in phytoplankton and was probably caused by high turbidity. Certainly many reports associated reduced phytoplankton density with turbid conditions 

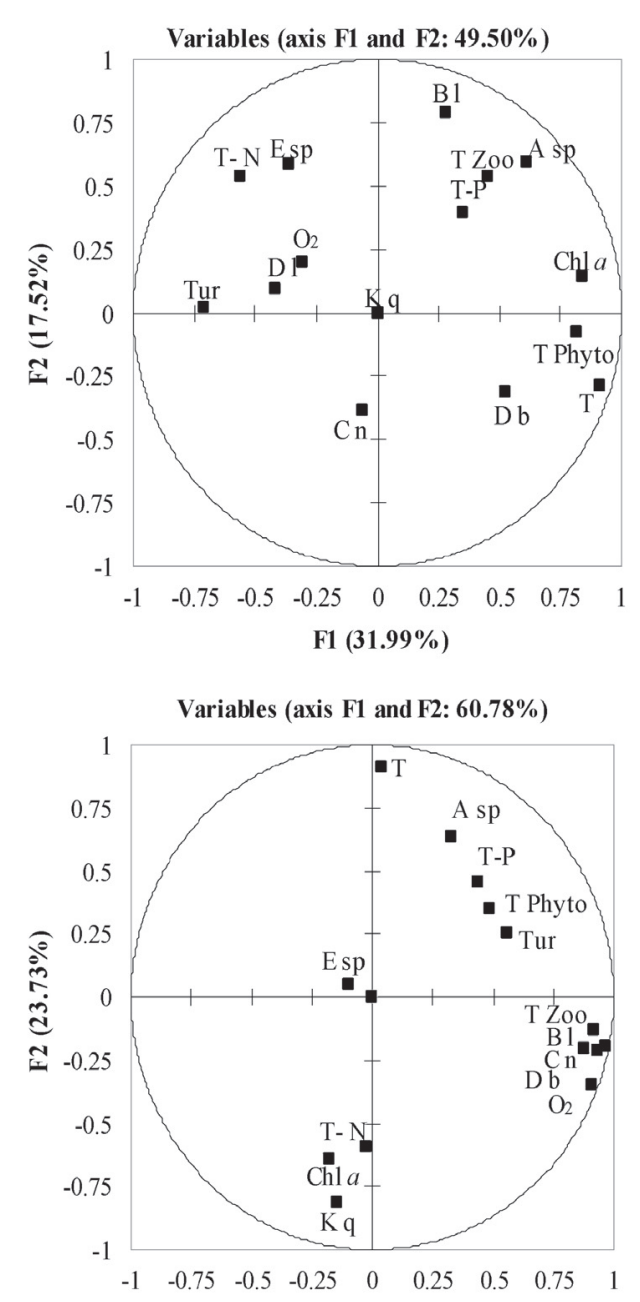

F1 (37.05\%)

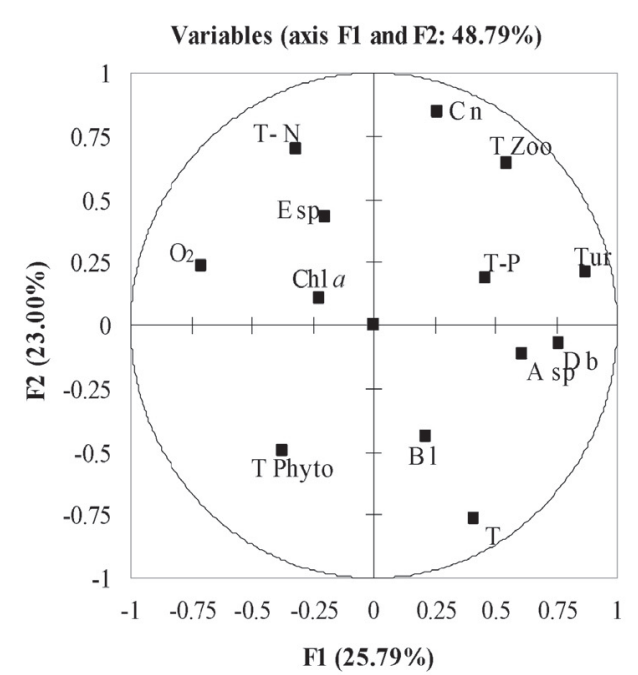

Fig. 9. Principal Component Analysis (PCA) (Axis I and II) of the total zooplankton and total phytoplankton abundance and selected environmental variables in the Kasseb (a), Mornaguia (b) and Ghdir El Goulla (c) reservoirs: (T): water temperature, $\left(\mathrm{O}_{2}\right)$ dissolved oxygen, (Tur): turbidity, (T-N): total nitrogen, (T-P): total phosphorus, (T Zoo): total zooplankton, (T Phyto) total phytoplankton, $(\mathrm{Chl} a)$ : chlorophyll $a$, (C n): Copidodiaptomus numidicus, (E sp): Eudiaptomus sp., (A sp):
(Ariyadej et al., 2004). In the three reservoirs, there was an imbalance between algae biomass and the zooplankton, since the assimilation rate of these consumers was not covered by phytoplankton biomass alone. In this kind of situation, detritus food chains were also probably found to be a resource for zooplankton; as reported by several authors (Araújo and Pinto-Coelho, 1998).

Higher concentrations of total nitrogen $\left(10.9 \mathrm{mg} . \mathrm{L}^{-1}\right.$ in December at a depth of $5 \mathrm{~m}$ ) and total phosphorus $\left(0.2 \mathrm{mg} . \mathrm{L}^{-1}\right.$ in August at a depth of $\left.10 \mathrm{~m}\right)$ were found in Kasseb reservoir, probably due to the input of nutrients through the main tributaries and a release of sediments. Nutrient availability determines potential phytoplankton biomass, while the grazing rate by zooplankton determines how much of this potential is realized (Carpenter, 1991). The relationship between phytoplankton and zooplankton was evidenced by a comparison of further changes in density of both communities in the three reservoirs. Subsequently, each decrease in the numbers of algae was preceded by an increase in zooplankton density. In Kasseb reservoir the highest zooplankton density was found at the upper layer $(0-10 \mathrm{~m})$ with maximum at the depth of $5 \mathrm{~m}$ $\left(8.4 \times 10^{3}\right.$ ind. $\left.\mathrm{L}^{-1}\right)$. The vertical distribution of zooplankton was similar to those reported in other studies (Cadjo et al., 2007). Such pattern may be related to the food availability in the upper layer, where phytoplankton was mostly abundant. These findings confirm the results of Cherbi et al. (2008). Thus zooplankton is an important grazer of algae and it is well known during periods of high zooplankton abundance (Horn et al., 2008).

Cyclopoids copepods were the most abundant group averaging $65 \%$ of total zooplankton in Kasseb reservoir. In Mornaguia and Ghdir El Goulla reservoirs, calanoid copepods were the dominant groups representing $67 \%$ and $81 \%$ respectively. The range of total rotifers density found in the three reservoirs was much lower than that reported in various productive reservoirs (Whitman et al., 2004). Zooplankton species composition can differ markedly between the three reservoirs. Two species of calanoid copepods (Copidodiaptomus numidicus and Eudiaptomus sp.) and one cyclopoids copepods (Acanthocyclops sp.) were common in the three reservoirs studied. Daphnia longispina $\left(68.2 \pm 77.5\right.$ ind. $\left.\mathrm{L}^{-1}\right)$ and Ceriodaphnia quadrangula $\left(0.95 \pm 0.95\right.$ ind. $\left.\mathrm{L}^{-1}\right)$ were present only in Kasseb reservoir (Table 2). The highest density of Bosmina longirostris $\left(1.35 \times 10^{2} \pm 1.54 \times 10^{2}\right.$ ind. $\left.\mathrm{L}^{-1}\right)$ was registered in Kasseb reservoir (Table 2). Whereas, Diaphanosoma brachyurum was dominant in Mornaguia $\left(2.35 \times 10^{2} \pm\right.$ $3.12 \times 10^{2}$ ind. $\mathrm{L}^{-1}$ ) (Table 2). The low diversity and density of the species occurring in Ghdir El Goulla reservoir can be an indication of environmental stress. This phenomenon coincided with results reported by Green (1993).

Acanthocyclops sp., (B 1): Bosmina longirostris, (D b) Diaphanosoma brachyurum, (D 1): Daphnia longispina, (C q): Ceriodaphnia quadrangula, (K q): Keratella quadrata. 
Table 3. Trophic level index, TSI, with chlorophyll $a$ (Chl $a)$ and total phosphate (Total-P) concentrations.

\begin{tabular}{|c|c|c|c|}
\hline \multirow[b]{2}{*}{ Trophic level index } & \multicolumn{3}{|c|}{ Reservoirs } \\
\hline & Kasseb & Mornaguia & $\begin{array}{c}\text { Ghdir } \\
\text { El Goulla }\end{array}$ \\
\hline Carlson and Simpson (1996) & & & \\
\hline $\operatorname{TSI}_{\mathrm{C}}($ Chlorophyll $a)$ & 40.3 & 40.1 & 39.7 \\
\hline TSI $_{C}$ (Total phosphorus) & 16.0 & 16.1 & 15.8 \\
\hline Trophic state & \multicolumn{3}{|c|}{ Oligo-mesotrophic } \\
\hline \multicolumn{4}{|l|}{ Burns et al. (2000) } \\
\hline $\mathrm{TL}_{\mathrm{B}}($ Chlorophyll $a)$ & 4.7 & 4.6 & 4.4 \\
\hline $\mathrm{TL}_{\mathrm{B}}$ (Total phosphorus) & 2.0 & 2.0 & 1.9 \\
\hline Trophic state & \multicolumn{3}{|c|}{ Mesotrophic } \\
\hline OCDE (1982) & \multirow{2}{*}{\multicolumn{3}{|c|}{ Mesotrophic }} \\
\hline Trophic state & & & \\
\hline
\end{tabular}

Ghdir El Goulla was receiving the water from Mornaguia (61\% of total external input) and Kasseb (39\% of total external input). These water movements had essential implications for the chemistry and biology of Ghdir El Goulla water bodies. Zooplankton community of this latter depended probably on the artificially introduced water of Kasseb and Mornaguia reservoirs. However the absence of Daphnia longispina, Ceriodaphnia quadrangula and Keratella quadrata in Ghdir El Goulla was explained by the stressful effect of pipeline.

Synthesis of all observations was provided by principal component analysis of the results. The interpretation of the two axes allowed a confirmation of the following: The first axis positively selected the temperature, total zooplankton, total phosphorus and Diaphanosoma brachyurum in Kasseb, contrary to the negatively selected dissolved oxygen and total nitrogen, Eudiaptomus sp. in Kasseb and Ghdir El Goulla reservoirs (Figs. 9a and 9c). Furthermore a positive relationship was shown between Diaphanosoma brachyurum on the first PCA axis in Mornaguia and Ghdir El Goulla reservoirs (Figs. 9b and 9c). This is a confirmation of the impact of artificially introduced external zooplankton input in Ghdir El Goulla reservoir.

Our study shows that the total phosphorus and chlorophyll a concentration indicates an oligomesotrophic (Carlson and Simpson, 1996) or mesotrophic status (OCDE, 1982; Burns and Bryers, 2000) (Table 3). Detailed measurements of nutrients associated with phosphorus and nitrogen might be taken for correlations with trophic state, chlorophyll $a$ and total phosphorus, common patterns in freshwater ecology analyses (PintoCoelho et al., 2005).

These results are supported by the principal component analysis (PCA) (Fig. 10). The first two axes of PCA permit the following interpretations: The first axis reflects the trophic gradient and temporal distribution of the zooplankton communities of these reservoirs studied. If we consider that the increase in total phosphorus, chlorophyll $a$, the total zooplankton densities levels and corresponds to increased gradient of eutrophicated of the system, the relative distribution of sample vectors of each

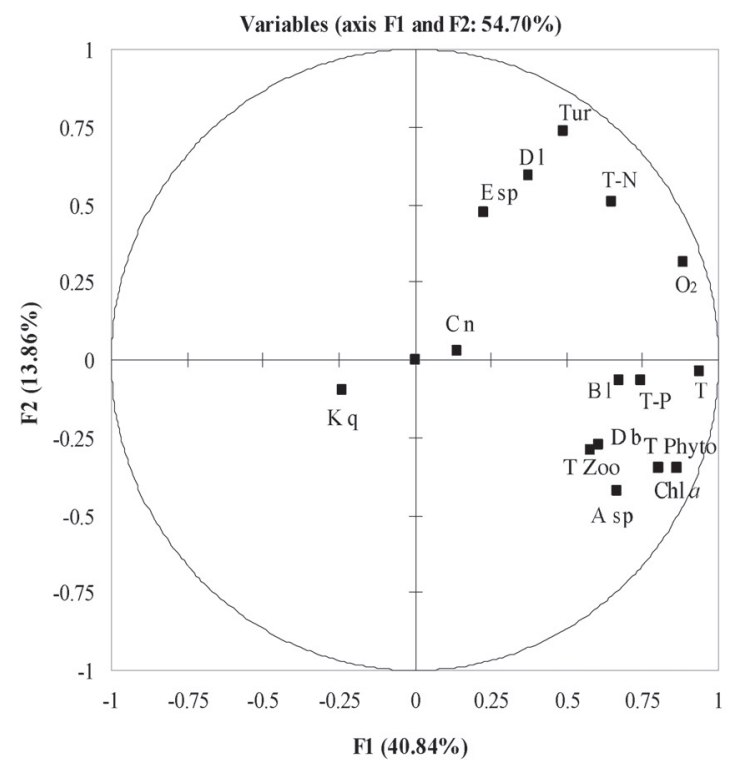

(a)

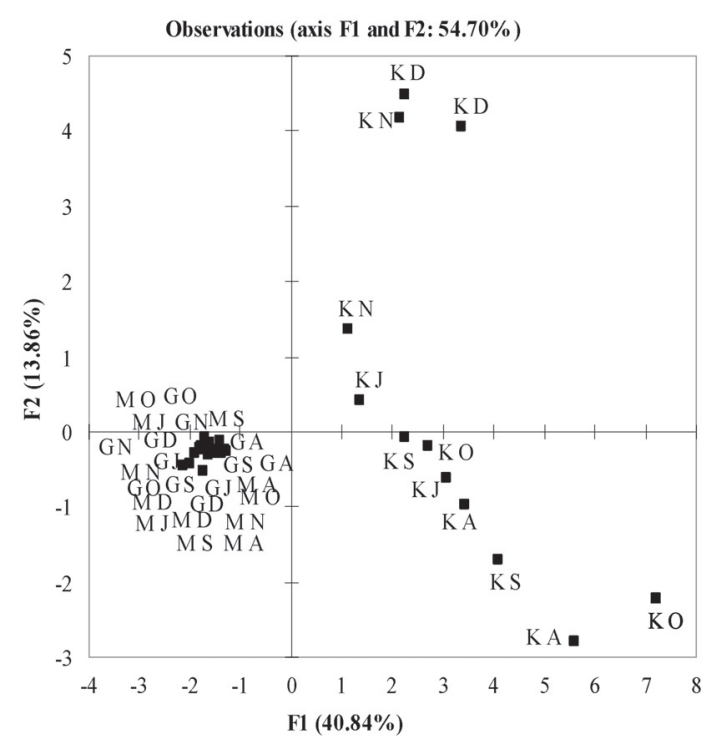

(b)

Fig. 10. Principal Component Analysis (PCA) (Axis I and II) on mean values of environmental and biological variables in the Kasseb (K), Mornaguia (M) and Ghdir El Goulla (G) reservoirs: Plots of the variables (a) and for each sampling data (b); J, A, S, $\mathrm{O}, \mathrm{N}$ and $\mathrm{D}$ indicate the months.

reservoir indicates that Kasseb is the most eutrophicated reservoir. Indeed, the species Acanthocyclops sp., Bosmina longirostris and Diaphanosoma brachyurum were positioned more closely to Kasseb reservoir. Cyclopoids was observed by some workers (Branco and Senna, 1996) at high trophic levels. Many studies reported that Bosmina longirostris was the abundant species during the periods of increased nutrients inflow (De Eyto, 2001). The species Diaphanosoma brachyurum was generally abundant at high trophic levels (Amoros, 1984). While calanoids occupied a distinct position, in association with more oligotrophic reservoirs (Mornaguia and Ghdir El Goulla). Calanoid copepods were the dominant species under oligomesotrophic conditions (Pinto-Coelho et al., 2005). 


\section{Conclusion}

Environmental factors play an important role in the seasonal variation of the zooplankton in the Kasseb and Mornaguia reservoirs. Zooplankton community of Ghdir El Goulla reservoir was influenced by the impact of internal environmental factors and artificially introduced water from both Kasseb and Mornaguia reservoirs. The highest density and diversity of zooplankton species were recorded in Kasseb reservoir, which indicated an increased tendency for eutrophication. Mornaguia and Ghdir El Goulla are oligo-mesotrophic reservoirs. Understanding the relationship between the zooplankton community and its temporal distribution is significant for the comprehension of trophic interactions within these reservoirs. The present data indicate the necessity of proper water treatment to prevent these small water-bodies, since they are drinking water supply of vital importance to Tunisia.

Acknowledgements. We would like to express our gratitude to everyone who has contributed to the elaboration of the present investigation. This work was conducted as part of a collaborative project between the University of Sfax (Tunisia) and the University of Sidi-Mohammed-Ben-Abdallah, Biology department, Science Faculty (Fès-Atlas, Morocco). We thank the anonymous referees for the helpful advice and comments. This study was supported by the Tunisian Ministry of Scientific Research and Technology. We would like also to thank especially Drira Z. and Guermazi W. for their technical help.

\section{References}

Aka M., Pagano M., Saint-Jean L., Arfi R., Bouvy M., Cecchi P., Corbin D. and Thomas S., 2000. Zooplankton variability in 49 shallow tropical reservoirs of Ivory Coast (West Africa). Int. Rev. Hydrobiol., 85, 491-504.

Amoros C., 1984. Introduction pratique à la systématique des organismes des eaux continentales françaises. Crustacés cladocères. Bull. Soc. Linn. Lyon, 53, 72-145.

Andronikova I.N., 1993. Lake Classification with Respect to Biological Productivity. In: Teoreticheskie voprosy klassifikatsii ozer (Theoretical Problems of Lake Classification), St. Petersburg: Nauka.

Araújo M.A. and Pinto-Coelho R.M., 1998. Produção e consume de carbono orgânico na comunidade planctônica da represa da Pampulha, Belo Horizonte, MG. Rev. Bras. Biol., 58, 403-414.

Ariyadej C., Tansakul R., Tansakul P. and Angsupanich S., 2004. Phytoplankton diversity and its relationships to the physico-chemical environment in the Banglang Reservoir, Yala Province, Songklanakarin. J. Sci. Technol., 26, 5, 595-607.

Baykal T., Salman S. and Açikgöz Ü., 2006. The Relationship between Seasonal Variation in Phytoplankton and Zooplankton Densities in Hirfanlı Dam Lake (Kırşehir, Turkey). Turk. J. Biol., 30, 217-226.

Branco C.W.C. and Senna P.A.C., 1996. Relations among heterotrophic bacteria, chlorophyll- $a$, total phytoplankton, total zooplankton and physical and chemical features in the
Paranoá reservoir, Brasília, Brazil. Hydrobiologia, 337, 171-181.

Burns N. and Bryers G., 2000. Protocol for Monitoring Trophic Levels of New Zealand lakes and Reservoirs, Lakes Consulting, Pauanui, New Zealand.

Cadjo S., Miletic A. and Djurkovic A., 2007. Zooplankton of the Potpec reservoir and the saprobiological analysis of water quality. Desalination, 213, 24-28.

Carlson R.E. and Simpson J., 1996. A Coordinator's Guide to Volunteer Lake Monitoring Methods, North American Lake Management Society, $96 \mathrm{p}$.

Carpenter S.R., Frost T.M., Kitchell J.F., Kratz T.K., Schindler D.W., Shearer J., Sprules W.G., Vanni M.J. and Zimmerman A.P., 1991. Patterns of primary production and herbivory in 25 North American lake ecosystems. In: Cole J., Lovett G. and Findlay S. (eds.), Comparative Analyses of Ecosystems: Patterns, Mechanisms, and Theories, Springer-Verlag, New York, 67-96.

Cherbi M., Lek-Ang S., Lek S. and Arab A., 2008. Distribution du zooplancton dans les lacs à climat méditerranéen. $C$. $R$. Biol., 331, 692-702.

Chessel D. and Dolédec S., 1992. ADE Software (Version 3.6), multivariate Analyses and Graphical Display for Environmental Data, User's Manual.

D'Elia C.F., Steudler P.A. and Corwin N., 1977. Determination of total nitrogen in aqueous samples using persulfate digestion. Limnol. Oceanogr., 22, 760-764.

De Eyto E., 2001. Chydorus sphaericus as a biological indicator of water quality in lakes. Verh. Int. Ver. Theor. Angew. Limnol., 27, 3358-3362.

Dejen E., Vijverberg J., Nagelkerke L.A.J. and Sibbing F.A., 2004. Temporal and spatial distribution of microcrustacean zooplankton in relation to turbidity and other environmental factors in a large tropical lake (L. Tana, Ethiopia). Hydrobiologia, 513, 39-49.

DGEDA, 2004. Budget économique de l'agriculture et de la pêche, $95 \mathrm{p}$.

Fernández-Rosado M.J. and Lucena J., 2001. Space-time heterogeneities of the zooplankton distribution in La Concepción reservoir (Istán, Málaga; Spain). Hydrobiologia, 455, 157-170.

Frontier S., 1973. Étude statistique de la dispersion du zooplancton. J. Exp. Mar. Biol. Ecol., 12, 229-262.

Green J., 1993. Diversity and dominance in planktonic rotifers. Hydrobiologia, 255/256, 345-352.

Guevara G., Lozano P., Reinoso G. and Villa F., 2009. Horizontal and seasonal patterns of tropical zooplankton from the eutrophic Prado Reservoir (Colombia). Limnologica, 39, 128-139.

Horn H. and Horn W., 2008. Bottom-up or top-down - How is the autotrophic picoplankton mainly controlled? Results of long-term investigations from two drinking water reservoirs of different trophic state. Limnologica, 38, 302-312.

Karabin A., Ejsmont-Karabin J. and Kornatowska R., 1997. Eutrophication processes in a shallow, macrophytedominated lake-factors influencing zooplankton structure and density in Lake Luknajno (Poland). Hydrobiologia, 342/ 343, 401-409.

Korovchinsky N.M., 1992. Sididae et holopediidae (Crustacea: Daphniiformes), Guides to the identification of the Microinvertebrates of the continental of the word 3, SPB Academic Publishing, $85 \mathrm{p}$. 
Ludovisi A. and Poletti A., 2003. Use of thermodynamic indices as ecological indicators of the development state of lake ecosystems: 2. Exergy and specific exergy indices. Ecol. Model., 159, 223-238.

Margaritora F.G., 1985. Cladocera. Fauna d'Italia, Bologna, $399 \mathrm{p}$.

Murphy J. and Riley J.P., 1962. A modified single solution method for the determination of phosphate in natural waters. Annal. Chim. Acta., 27, 31-36.

OCDE, 1982. Eutrophisation des eaux: méthodes de surveillance, d'évaluation et de lutte, OCDE, Paris, $165 \mathrm{p}$.

Osore M.K., Tackx M.L. and Daro M.H., 1997. The effect of rainfall and tidal rhythm on community structure and abundance of the zooplankton of Gazi bay, Kenya. Hydrobiologia, 356, 117-126.

Pinto-Coelho R., Pinel-Alloul B., Méthot G. and Havens K.E., 2005. Crustacean zooplankton in lakes and reservoirs of temperate and tropical regions: variation with trophic status. Can. J. Fish. Aquat. Sci., 62, 348-361.
Rodier J., 1984. Analyse de l'eau, Édition Dunod, Paris, $1135 \mathrm{p}$.

Rogozin A.G., 2000. Specific Structural Features of Zooplankton in Lakes Differing in Trophic Status: Species Populations. Russ. J. Ecol., 31, 405-410.

Shannon C.E. and Weaver G., 1949. The Mathematical Theory of Communication, University of Illinois Press, Urbana, Chicago, USA.

Utermöhl H., 1958. Zur Vervollkommung der quantitativen Phytoplankton methodik. Mitt. Int. Verein. Limnol., 9, $1-38$.

Whitman R.L., Nevers M.B., Goodrich M.L., Murphy P.C. and Davis B.M., 2004. Characterization of Lake Michigan coastal lakes using zooplankton assemblages. Ecol. Indic., 4, 277-286.

Zadereev Y.S. and Tolomeyev A.P., 2007. The vertical distribution of zooplankton in brackish meromictic lake with deep-water chlorophyll maximum. Hydrobiologia, 576, 69-82. 